удк 331.101

\title{
ТЕХНОЛОГІЇ МОТИВАЦІї ПЕРСОНАЛУ ПІДПРИЄМСТВ У СУЧАСНИХ УМОВАХ
}

\section{TECHNOLOGIES OF MOTIVATION OF PERSONNEL OF ENTERPRISES IN MODERN CONDITIONS}

\author{
Литвишко Лілія Олександрівна \\ кандидат економічних наук, доцент, \\ Національний транспортний університет \\ ORCID: https://orcid.org/0000-0001-9315-046X \\ Марченко Павло Анатолійович \\ магістр, \\ Національний транспортний університет \\ ORCID: https://orcid.org/0000-0003-1224-5411 \\ Lytvyshko Liliia, Marchenko Pavlo \\ National Transport University
}

\begin{abstract}
У статті розкрито поняття «мотивація» та контекст, який його характеризує. Розглянуто види мотивації і особливості для підтримки та розвитку праці персоналу, що стимулюють трудову діяльність. Визначено способи, які можуть призвести до ймовірного зниження та підвищення трудової діяльності працівників підприємств. Представлено способи надання оцінок щодо визначення мотиваційного рівня праці для персоналу. Визначено, що «потреба» - $є$ невід'ємною складовою у частині людини, що потребує її підтримки та подальшого вдосконалення якості мотиваційного рівня у працівників трудової діяльності. Описано технології для мотивації персоналу, які допоможуть забезпечити їхні мотиви та потреби, що ефективно та позитивно вплинуть на їх подальші якості трудових відносин на користь статусів підприємств та зроблені певні висновки.
\end{abstract}

Ключові слова: мотивація, персонал, потреба, задоволення, мотиваційні технології, результат праці, трудові відносини.

В статье раскрыто понятие «мотивация» и контекст, его характеризует. Рассмотрены их виды и особенности для поддержания труда персонала, стимулирующих трудовую деятельность. Определены способы, которые могут привести к возможному снижению и ее повышение для трудовой деятельности у работников предприятий. Предоставлены способы предоставления оценок по определению мотивационного уровня для персонала труда. Определено, что «потребность» - является неотъемлемой составляющей в части человека, нуждается в ее поддержке и дальнейшему совершенствованию качества мотивационного уровня у работников трудовой деятельности. Описанные технологии для мотивации персонала, которые помогут обеспечить их мотивы и потребности, эфрфективно и положительно повлияют на их дальнейшие качества трудовых отношений в пользу статусов предприятий и сделаны определенные выводы.

Ключевые слова: мотивация, персонал, потребность, удовлетворение, мотивационные технологии, результат труда, трудовые отношения.

The article reveals the concept of "motivation" and the context that characterizes it. Their types and features for support of work of the personnel stimulating labor activity are considered. The ways which can lead to probable decrease and its increase for labor activity at employees of the enterprises are defined. Methods of providing assessments to determine the level of motivation for staff are provided. It is determined that "need" is an integral part of a person who needs its support and further improvement of the quality of motivational level of employees. Ways to effectively motivate workers are always determined individually and carefully, depending on human abilities. That is why there are problems in assessing the quality of human labor in the staff of enterprises. It became clear that to achieve a high motivational character in the floating important factors, the so-called "stimulation" and "motive". These factors are not an integral part of the realization of motivations in the human nature of society. In this case, each staff has a personal manager with a psychological portrait, which can affect the outcome of work from each of his subordinates. Managers are able to accept not only encouragement, but also the opportunity to experience this result in the enterprise. Most companies have their own staff motivation systems for employees. There is often 
a need for a new employee to be given additional benefits that provide value to the company. The main reason for the variety of motivation systems is human needs. The emphasis in motivating young professionals is formed in application technologies. The existence of motivational technologies is the most effective system for motivating staff. Much attention is paid to the development of technologies that may include motivational packages for young professionals, provided in the event of increased competitiveness in the labor market. Technologies for motivating staff to help ensure their motives and needs, which will effectively and positively affect their further quality of employment in favor of the status of enterprises, and certain conclusions are made.

Keywords: motivation, personnel, need, satisfaction, motivational technologies, result of work, labor relations.

Постановка проблеми. Ефрективність управління персоналом не обходитися без визначення і розуміння потреб співробітника, його мотивів. Під суспільними і особистими цілями завжди є основа управління людськими ресурсами на підприємствах. Вибір єдиної економічно-виробничої мети $€$ головним завданням для співробітників на всіх рівнях управління і ставить врахування важливої фрункції сучасного менеджменту - мотивації.

Для життєдіяльності підприємства треба об'єднувати дії людей, також поділяти роботи між співробітниками на підприємстві, а найголовніше - це існування спільної мети в організації. Об'єднання можливо реалізувати, якщо кожен співробітник підприємства буде знати, 3 ким, коли, що, і де робити, тому, все це дозволяє досягати цілей, що недосяжні одному співробітнику, а також вирішує теперішні проблеми управління. Відносини між організацією і співробітником - це обмін винагороди і результатів від їх роботи, які протиставляють загальні інтереси, також створюються тяжкі моменти при самовіддачі співробітника і обмежується його внесок в життєдіяльність підприємства, що сплачує винагороду. Найважливіше, що для виконання будь-якої діяльності, у працівників мусить буть зацікавленість в остаточному результаті робіт. Іноді, особливість роботи полягає в тому, що результат буде фрормуватися протягом усього процесу, тому для отримання більш високих результатів потрібно докласти всіх зусиль і уваги співробітника, не тільки в процесі виконання роботи, а й також до завершення процесу роботи.

Актуальність даної статті полягає в тому, що існує багато мотиваційних фракторів, тому, вмотивована організація роботи працівників на підприємствах стає все більш цікавою, змістовною і творчою. Ефективний розвиток набувається на тих підприємствах, які займаються підвищенням якості життя співробітників, розвитком персоналу та стимулюванням участі співробітників в управлінні компанії.

Аналіз останніх досліджень і публікацій. Дослідження соціально-трудових від- носин та їх вплив на фрормування мотивації трудової діяльності висвітлені в роботах Б. Генкина, В. Адамчука, А. Колота, Г. Беккера, Дж. К. Гелбрейта, А. Маслоу, Д. Мак-Грегора і ін. Проблеми мотивації трудової діяльності розглядаються в роботах вчених і практиківекономістів під різними кутами зору. В роботах М. Альберта, М. Мескон, Ф. Хедоурі відображені розробки щодо використання мотивації трудової діяльності.

Виділення невирішених раніше частин загальної проблеми. У роботах вищезгаданих авторів не була приділена значна увага в дослідженнях питання щодо використання технологій для мотивування персоналу в сучасних умовах ведення підприємницької діяльності.

Формулювання цілей статті. Метою статті $€$ дослідження особливостей мотиваційних технологій для персоналу підприємств у сучасних умовах ведення підприємницької діяльності.

Виклад основного матеріалу дослідження. Мотивація професійної діяльності демонструє свої взаємозв'язки, цілі та потреби особистих якостей, що стимулюють важливі якості для здійснення і досягнення певних цілей для профресійної діяльності. Мотивація та стійкість поведінки розрізняються у багатьох людей, що може змінити будь-яку людину з певним часом. Поняття «мотивація» в ролі управління організаційною поведінкою розглядає в собі процес пояснення інтенсивності, наполегливості і спрямованості спроб для досягнення мети. Коли ми говоримо про мотивацію, то предметом цього аналізу становиться не поведінка, а результати діяльності людей.

У загальному розумінні мотивація - це сукупність рушійних сил, які спонукають людину до виконання певних дій. Ці сили можуть мати як зовнішнє, так і внутрішнє походження і змушувати людину свідомо чи несвідомо робити ті чи інші вчинки [1].

У теорії мотивації розділяються на такі види мотивації: зовнішня та внутрішня. Зовнішня мотивація являє собою статус посади, рівень 
заробітної плати, відносини з керівництвом і товаришами по службі, напруженість роботи і т.д. Внутрішня мотивація демонструє внутрішні мотиви такі як любов до своєї справи, гордість профресією, задоволеність місцем і характером роботи і т.д.

Мотив - усвідомлене внутрішнє спонукання людини до діяльності, пов'язане із задоволенням певних потреб. Мотиви притаманні людині і $€$ внутрішніми спонукальними причинами [2].

Моделі мотивів «досягнення успіху» та «уникнення невдач» щодо людської праці представлено в таблиці 1.

Найпоширеніші демотиватори гаслами вважаються наступні:

1. Все повинно бути в кращому вигляді.

2. Виконуйте все правильно.

3. Робіть все швидко.

4. Працюйте завжди напружено.

5. Будьте зразками для наслідування.

Дані демотиватори гаслами швидко призводять до виснаження фрізичного, професійного і психологічного ресурсу персоналу, що $€$ наслідком для зниження продуктивності, викликають апатією і підвищення виробничого травматизму.

Для подолання негативних тенденцій можливі корекції процесів діяльності, які можуть мати наступну спрямованість:

1. створення протоколів тимчасових витрат для здійснення незалежного контролю інтенсивності праці;

2. побудова ієрархії завдань для оперативного прийняття рішень про можливі перестановки завдань, визначення їх пріоритетності;

3. чітка десрініція цілей діяльності для визначення співвідношення конкретного завдання і спільної мети діяльності;

4. корекція комунікації для прискорення обміну інорормацією та навчання персоналу для правильного її використання.
Мотиваційні технології пов'язується із перерахуванням їх оцінок та навчань. Оцінка, навчання та мотивація для персоналу в її діяльності містить в собі єдиний технологічний комплекс, що при правильних обраних критеріях для оцінювання персоналу, співробітники підприємства можуть надати допомогу в отриманні нових навичок, які сорормують мотивації досягнень. Мотивація досягнення допоможе співробітникам не тільки покращити результат праці чи підвищити прагнення до кар'єрного росту або росту доходів від просресійної діяльності, але й зорієнтується на їх навчання та вміннях. Дані зусилля оцінюються підприємством, що усвідомить зміст кадрової діяльності.

3 нейрофрізіологічної точки зору, «потреба» - це домінанта, яка передбачає збудження цільових механізмів у головному мозку людини, які тісно пов'язані із поведінковими актами. Потреба виникає у мотиваційному збудженні із її нервових центрів, які приводять організм до визначеного виду діяльності. Усі нові потреби є головним стимулом у просуванні окремих особистостей та у суспільстві в цілому.

Потреба - це дотримання необхідних оптимальних параметрів для коморортного стану життєздатності організму.

Потреби набуваються при виникненні дискомсрортів, i, це спрямовує на психіку певної людини, у якої підвищена роздратованість та збудливість на інші дії.

Рівень задоволення демонструє поведінковий стан людини до її встановленої мети у будь-яких ситуаціях. Людство постійно повторює поведінку, яку порівнюють із їхніми потребами та уникають поведінки, що порівнюють 3 їх незадоволеними потребами.

Дані поведінки відображені на рисунку 1.

Головним інструментом для мотиваційних змін в трудових відносинах $€$ «колективний

Моделі мотивів «досягнення успіху» та «уникнення невдачі»

Таблиця 1

\begin{tabular}{|c|l|l|}
\hline $\begin{array}{c}\text { № } \\
\text { 3/n }\end{array}$ & \multicolumn{1}{|c|}{ Мотив «досягнення успіху» } & \multicolumn{1}{c|}{ Мотив «уникнення невдач» } \\
\hline 1 & потреба в успіху і праці & потреба уникати невдачі \\
\hline 2 & $\begin{array}{l}\text { інструментальна діяльність щодо } \\
\text { досягнення мети }\end{array}$ & $\begin{array}{l}\text { інструментальна діяльність для уникнення } \\
\text { невдач }\end{array}$ \\
\hline 3 & очікування успіху & упевненість в успіху або в неуспіху \\
\hline 4 & похвала за виконану роботу & критика й осуд \\
\hline 5 & позитивно забарвлені відчуття & негативні відчутяя й невдача \\
\hline 6 & тема успіху & тема невдачі \\
\hline
\end{tabular}

Джерело: зроблено на основі [3, с. 640-641] 


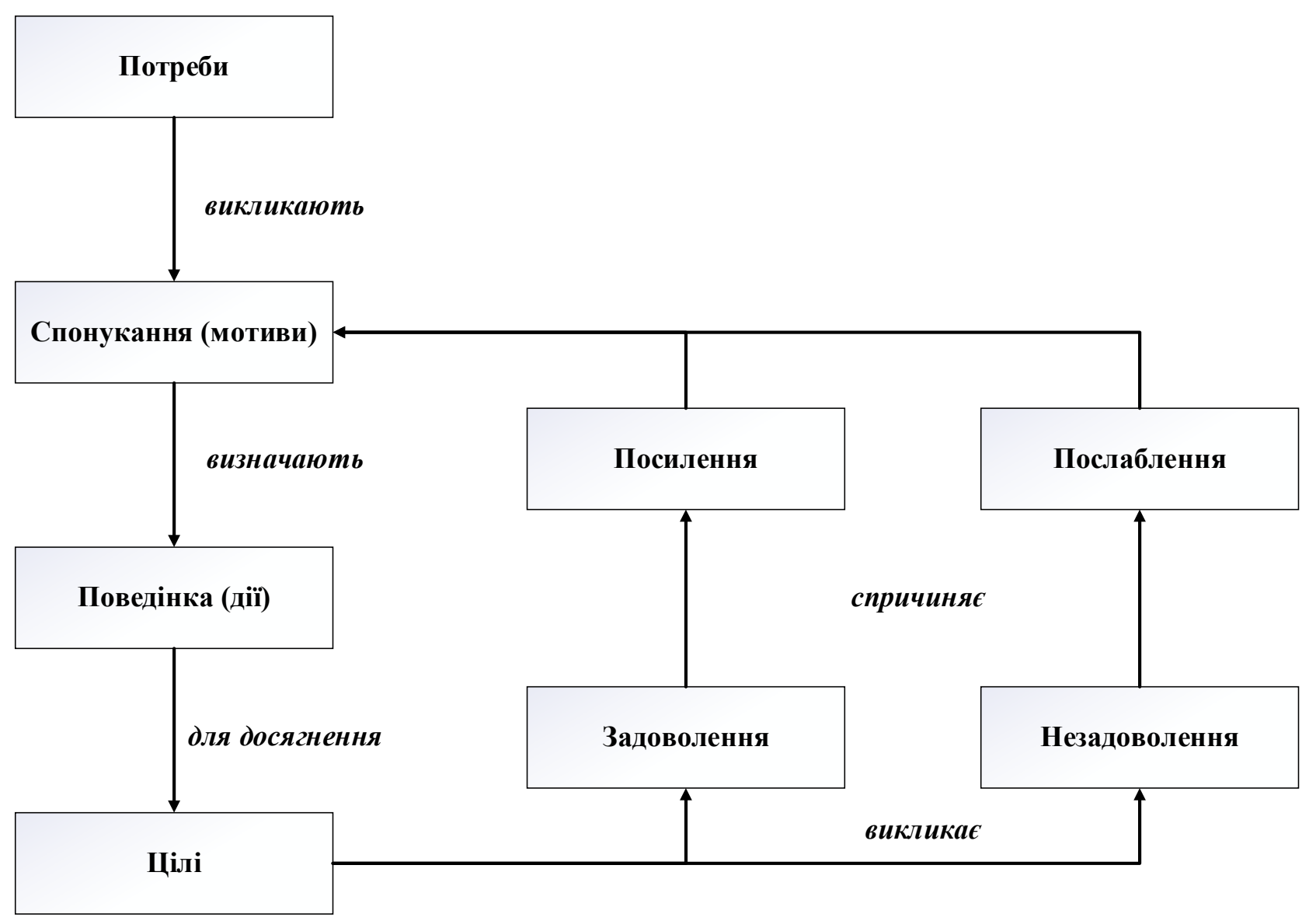

Рис. 1. Модель поведінкової мотивації за рахунок потреб

Джерело: удосконалено на основі [4]

договір», який містить принципово нові положення для співробітників і їх керівних в діяльності підприємств.

Колективний договір - угода, яка укладається між власником або уповноваженим органом (особою) і одним або кількома профрспілковими чи іншими уповноваженими на представництво трудовим колективом органами, а у разі відсутності таких органів - представниками трудящих, обраними та уповноваженими трудовим колективом. Колективний договір є результатом соціального партнерства та діалогу на локальному рівні [5].

Колективний договір став так званою формулою для розрахунку заробітної плати для більшості підприємств. Вона включала два елементи: ескалаційне застереження, яка дозволяла розраховувати допомоги по заробітній платі для співробітників з урахуванням змін у вартості життя, і коефріцієнт річного підвищення, який гарантував співробітникам регулярні надбавки за збільшення продуктивності завдяки застосуванню передових технологій. Ця мотиваційна фрормула стала спробою ввести новий елемент передбачуваності в програму заробітної плати, а також знизити напруженість під час обговорення рівня заробітної плати.

Програма винагород може змінити ставлення до справи керівників, завдяки чому їх зусилля можуть бути безпосередньо пов'язані з процвітанням корпорації.

Проте, зазнаються зміни в мотиваційній політиці підприємств-конкурентів. Дані зміни спричиняють зниження конкурентоспроможності компенсаційних пакетів, насамперед заробітної плати, що пропонують підприємства працівникам різних груп. Воно не сприятиме залученню та утриманню компетентних працівників та формування їх лояльності.

Для цього потрібно здійснювати моніторинг мотиваційних програм (заходів, методів і засобів) та завчасно визначати рішення щодо цих коригувань. Воно потрібно для того, щоб завчасно склалися та змінювалися дані програми.

Мотиваційний моніторинг - це система постійного спостереження і контролю стану мотивації трудової діяльності $з$ метою його оперативної діагностики й оцінки в динаміці, прийняття ква- 
ліфікованих управлінських рішень в інтересах підвищення ефрективності виробництва [6, с. 27].

Підприємства можуть самостійно створювати необхідні їм методичні бази та організовувати проведення мотиваційного моніторингу. До організацій та проведення мотиваційного моніторингу підприємства можуть наймати незалежних срахівців чи співробітників консалтингових компаній. Ця практика $€$ більш поширенішою, що може надати такі результати:

- провадження масштабних та репрезентативних досліджень мотиваційних потреб персоналу;

- залучати додаткові технологічні рішення;

- підвищувати якість методичних матеріалів, що використовуються для забезпечення зворотного зв'язку;

- забезпечувати анонімність і коноріденційність тощо.
Висновки. Впровадження мотиваційної технології менеджменту для персоналу на підприємствах, має такі наслідки: постійно підвищувати культурний та освітній рівень, розвивати вторинні потреби, здійснювати активний моніторинг для цільових інтересів та цінності орієнтації кадрів, фрормувати морально-психологічні якості, активізувати процеси в децентралізації для управлінських впливів, провадити соціологічні дослідження для виявів мотиваційних потреб та інтересів.

Звичайно, хороша зарплата - кращий мотиватор, тому, всім керівникам слід пам'ятати одну річ: до них приходять за хорошими грошима і кар'єрним ростом, а йдуть - через гнітючу атмоссреру та неадекватне керівництво.

Отже, технології нематеріальної мотивації - кращі варіанти для більш якісної роботи без великих грошових витрат.

\section{СПИСОК ВИКОРИСТАНИХ ДЖЕРЕЛ:}

1. Мотивація персоналу : підручник. Київ : КНЕУ, 2002. 6 с.

2. Колот А.М., Цимбалюк С.О. Мотивація персоналу : підручник. Київ : КНЕУ, 2011. 16, [3] с.

3. Варій М. Й. Загальна психологія : підр. [для студ. вищ. навч. закл.], 3-тє вид. Київ : Центр учбової літератури, 2009. 1007 с. ISBN 978-966-364-817-0

4. Гриненко А.М., Джурбій Ю.О. Соціальні фактори мотиваційного механізму персоналу підприємства. Вісник Кам'янець-Подільського національного університету імені Івана Огієнка. Економічні науки. 2012. Вип. 6. C. 405-408. URL: http://nbuv.gov.ua/UJRN/vkpnuen_2012_6_107

5. Колективний договір. URL: https://uk.wikipedia.org/wiki/Колективний_договір

6. Калина А.В. Економіка праці : навч. посібник. Київ : МАУП, 2004. 272 с.

\section{REFERENCES:}

1. Motyvatsiia personalu [Staff motivation: Textbook]. Kyiv: KNEU, 2002. 6 p.

2. Kolot A.M., Tsymbalyuk S.O. (2011) Motyvatsiia personalu [Staff motivation: a textbook]. Kyiv: KNEU, 16, [3] p.

3. Variy M.Y. (2009) Zahalna psykholohiia [General psychology]. Kyiv: Center for Educational Literature, 1007 p. ISBN 978-966-364-817-0

4. Grinenko A.M., Jurbiy Y.O. (2012) Sotsialni faktory motyvatsiinoho mekhanizmu personalu pidpryiemstva [Social factors of the motivational mechanism of the personnel of the enterprise]. Bulletin of Kamyanets-Podilsky National University named after Ivan Ogienko. Economic sciences, vol. 6, pp. 405-408. Available at: http://nbuv.gov.ua/UJRN/vkpnuen_2012_6_107

5. Kolektyvnyi dohovir [Collective agreement]. Available at: https://uk.wikipedia.org/wiki/Колективний_договір

6. Kalina A.V. (2004) [Labor Economics: Textbook. manual]. Kyiv: IAPM, 272 p. 